\title{
Viruses in acute gastroenteritis in children in Pune, India
}

\author{
P. BRIGHT SINGH, M. A. SREENIVASAN AND KHORSHED M. PAVRI \\ National Institute of Virology, 20-A, Dr Ambedkar Road, Pune-411 001, India
}

(Accepted 30 September 1988)

\begin{abstract}
SUMMARY
A 2-year study from January 1981 to December 1982 was undertaken to determine the role of viruses in the causation of diarrhoea in hospitalized children in Pune, Maharashtra State, India. The stool samples of 426 children (213 diarrhoeal and 213 non-diarrhoeal controls) were investigated by electron microscopy and ELISA for the presence of viruses. Six morphologically distinct viruses were visualized : rotavirus, coronavirus-like particles (CVLP), adenovirus, astrovirus, calicivirus and small round virus-like particles (SRV). Rotavirus was detected in $28.6 \%$ of the diarrhoeal patients and in $1.4 \%$ of the controls. The frequency of infection with rotavirus was highest in the children aged less than 5 years. The mean age of rotavirus-positive patients was 11 months. Although rotavirus was detected in almost every month, there has a seasonal trend for colder months when CVLP cases were fewest. However, the prevalence of CVLP was greater in the control group $(23.0 \%)$ rather than in those with diarrhoea $(8.9 \%)$. In the control group, CVLP were detected more frequently during the summer months. An inverse relationship between CVLP and rotavirus was observed in children. Adenovirus, astrovirus, calicivirus and SRV were detected in a small proportion of children with and without clinical symptoms of gastroenteritis.
\end{abstract}

\section{INTRODUCTION}

Gastroenteritis, a self-limiting infectious disease with clinical symptoms of diarrhoea and vomiting, is common in Indian children below 2 years of age. The involvement of bacteria in the aetiology of gastroenteritis is fairly well established, but the role of viruses in the causation of the disease is not yet clear. There are a few published reports of the detection and visualization of rotavirus, coronaviruslike particles (CVLP), adenovirus, astrovirus, calicivirus and small round viruslike particles (SRV) in the stools of South Indian children with symptoms of diarrhoea (Holmes et al. 1974; Mathan et al. 1975; Panikar, Mathew \& Mathan, 1982). The aim of this study was to determine the role of viruses in the causation of diarrhoea in children. This communication reports the results of the 2 -year investigation of children, with or without the symptoms of diarrhoea, admitted to the Sassoon General Hospitals, Pune, Maharashtra State, India. 


\section{MATERIALS AND METHODS}

\section{Patients}

Diarrhoeal stools were collected between January 1981 and December 1982 from 213 infants and young children aged 2 days to 12 years admitted to the paediatric ward in the hospital. Stool specimens from an equal number of children admitted to the same wards for disorders other than diarrhoea were also obtained, and these constituted the 'controls'. Stool specimens were collected 1 or 2 days after admission to the hospital. The personal data on cases were obtained by interview and clinical data were extracted from hospital records.

\section{Stool suspension}

An approximate $10 \%$ suspension of stool sample was prepared in normal saline and the mixture was shaken several times, centrifuged at $3000 \mathrm{rev} . / \mathrm{min}$ for $15 \mathrm{~min}$. The supernatant was separated and stored at $-20^{\circ} \mathrm{C}$ until processed for electron microscopy and enzyme-linked immunosorbent assay.

\section{Electron microscopy (EM)}

The supernatant of the stool suspension was further spun at $150000 \mathrm{~g}$ for $60 \mathrm{~min}$ in a Beckman ultracentrifuge using an $\mathrm{Sw} 50 \cdot 1$ Rotor. The supernatant was discarded and the pellet was reconstituted and stained according to the methods described by Madeley et al. (1977). The specimens were examined in a Philips EM 301 electron microscope at $80 \mathrm{kV}$. At least 10 grid squares were examined for each specimen.

\section{Enzyme-linked immunosorbent assay (ELISA)}

The reagents employed for the detecton of rotavirus by ELISA (polyclonal) including the ELISA blocking test were kindly supplied by Dr T. H. Flewett, WHO Reference Centre for Rotavirus, Birmingham, UK. A modified double antibody sandwich ELISA was performed as described by Beards et al. (1984).

Meteorological data were kindly provided from the office of the Director, Agricultural Meteorology, Pune.

\section{RESULTS}

A total of 213 diarrhoeal and 213 non-diarrhoeal (control) patients were investigated during the period January 1981 to December 1982. Of the 213 diarrhoeal patients, $158(74 \cdot 2 \%)$ were infants below 1 year of age $46(21.6 \%)$ were between 1 and 4 years, and $9(4 \cdot 2 \%)$ belonged to the age group of 5-12 years. There were in all $116(54.5 \%)$ males and $97(45.5 \%)$ females. Of the 213 control cases $128(60 \cdot 1 \%)$ were infants, $77(36 \cdot 1 \%)$ were between 1 and 4 years and 8 $(3 \cdot 7 \%)$ were in the age group of 5-12 years; $134(62.9 \%)$ were males and 79 $(37 \cdot 1 \%)$ were females.

Overall, 83 out of the $213(39.0 \%)$ patients showing symptoms of diarrhoea and 62 out of the $213(29 \cdot 1 \%)$ controls were shedding in their stools one or more virus type(s) detectable by direct EM. In 75 out of $213(35 \cdot 2 \%)$ diarrhoeal patients and 57 out of $213(26 \cdot 8 \%)$ controls, only one type of virus was detected (Table 1 and 
Table 1. Detection of single virus type in the stool of patients

\begin{tabular}{lcc}
\multicolumn{1}{c}{ Virus } & Diarrhoeal patients & Control patients \\
Rotavirus & $47(22.06)^{*}$ & $3(1.41)$ \\
CVLP & $17(7.98)$ & $45(21 \cdot 1)$ \\
Adenovirus & $7(3.28)$ & $7(3.28)$ \\
Astrovirus & $1(0.47)$ & 0 \\
SRV & $3(1.41)$ & $2(0 \cdot 94)$ \\
$\quad$ Total & $75(35 \cdot 21) \dagger$ & $57(26 \cdot 76) \dagger$ \\
Number of & 213 & 213 \\
patients & & \\
examined & &
\end{tabular}

* The figures in parentheses indicate percentage.

$\dagger$ In addition 8 diarrhoeal patients and 5 controls yielded more than one virus type in the same stool sample which are presented in Table 2 .

Fig. 1). However, in 8 diarrhoeal and 5 non-diarrhoeal cases, more than one kind of virus was detected in the same stool sample (Table 2, Fig. 2).

The ELISA and EM techniques together identified $61(28.6 \%)$ rotavirus positive cases out of 213 diarrhoeal patients and only in $3(1.4 \%)$ of control cases. Of the 61 cases, 48 were detected by both ELISA and EM, 8 by ELISA alone and 5 by EM only.

Among the rotavirus-positives in diarrhoeal cases, $39(63.9 \%)$ were below 1 year of age and $22(36 \cdot 1 \%)$ were between 1 and 4 years. Rotavirus was not detected in the stools of 9 children aged 5-12 years. The youngest rotavirus positive patient was 8 days old and the oldest was 48 months (mean 11 months). Thirty-two $(27.6 \%)$ of 116 males and $29(29.9 \%)$ of 97 females had rotavirus and the difference in the incidence between males and females was not significant $(P>0.05)$.

The monthly prevalence of rotavirus and its relation to relative humidity, temperature, rainfall and also to the number of diarrhoeal admissions are shown in Fig. 3. Analysis month by month revealed the presence of rotavirus in most of the months during the study period. However, a higher percentage $(50.9 \%)$ of rotavirus-positive cases was observed during the cooler months of November and December in both years. The percentage positivity in monsoon and summer seasons was $15 \cdot 4$ and $23 \cdot 6 \%$ respecitvely.

The relation between the onset of diarrhoea and the finding of rotavirus in the stool is shown in Table 3 . In $\mathbf{7 5 . 4} \%$ of patients rotavirus was detected during the first week of the onset of diarrhoea. The percentage of patients shedding rotavirus in their stools decreased progressively from the second week onwards.

The duration of clinical features: diarrhoea, dehydration, fever, vomiting and cough, was assessed in children with and without rotavirus infection. The results are shown in Table 4 . Of the 213 diarrhoeal patients, 6 children died during the acute phase of illness. The stool specimens from these fatal cases were negative for rotavirus. However, coronavirus-like particles were detected in 2 and astrovirus in 1 case.

CVLP alone was detected in 17 out of $213(7.98 \%)$ diarrhoeal children compared to 45 out of $213(21.1 \%)$ in the control group. CVLP was detected along with adenovirus and SRV in 2 diarrhoeal patients and in 4 controls.

Although the overall prevalence of CVLP was low in diarrhoeal cases, the 

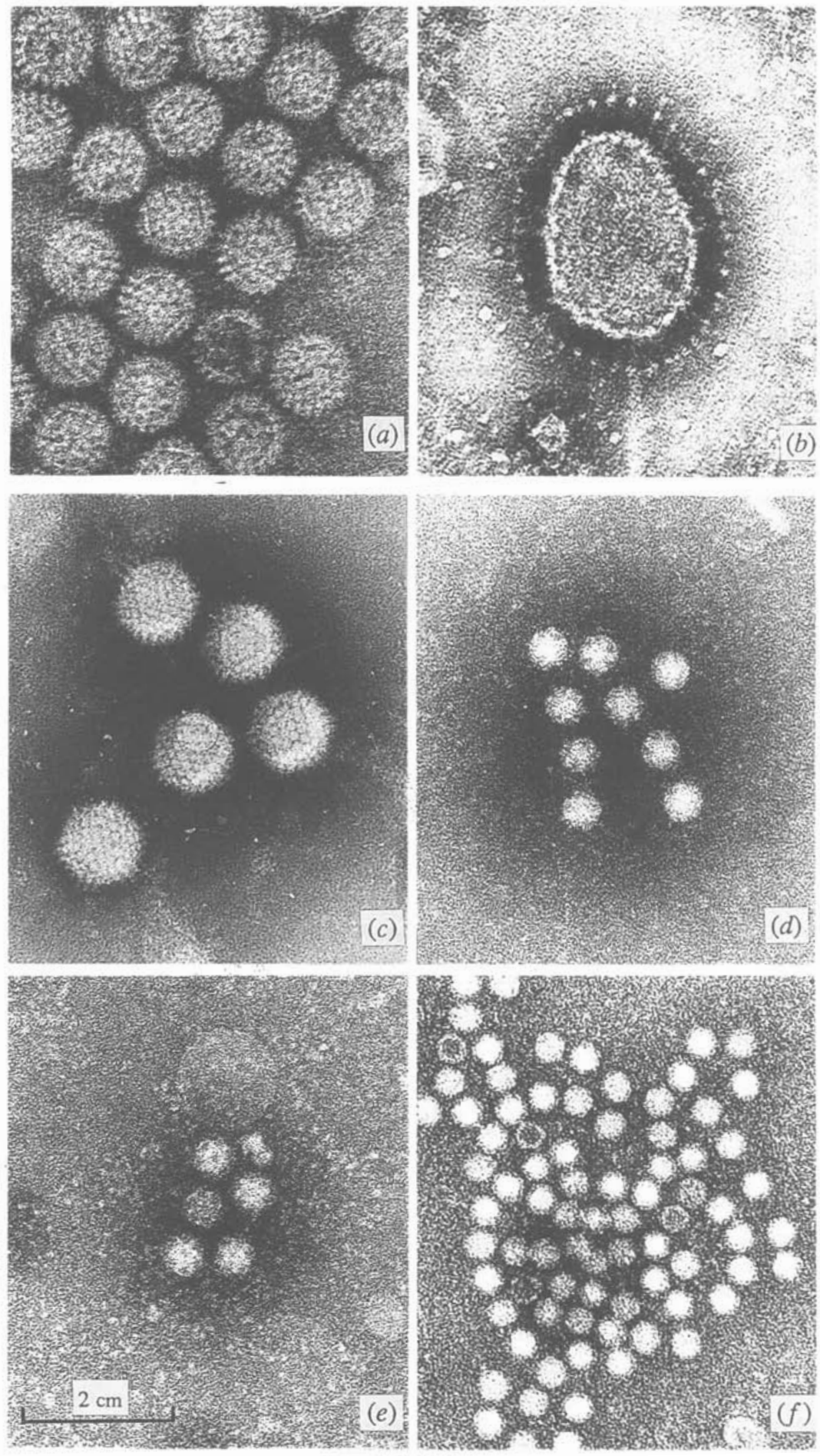

Fig. 1. Viruses detected in the stools. (a) Rotavirus, (b) coronavirus-like particles. (c) adenovirus, $(d)$ astrovirus, $(e)$ calicivirus, $(f)$ small round virus. Bar indicates $100 \mathrm{~nm}$. 

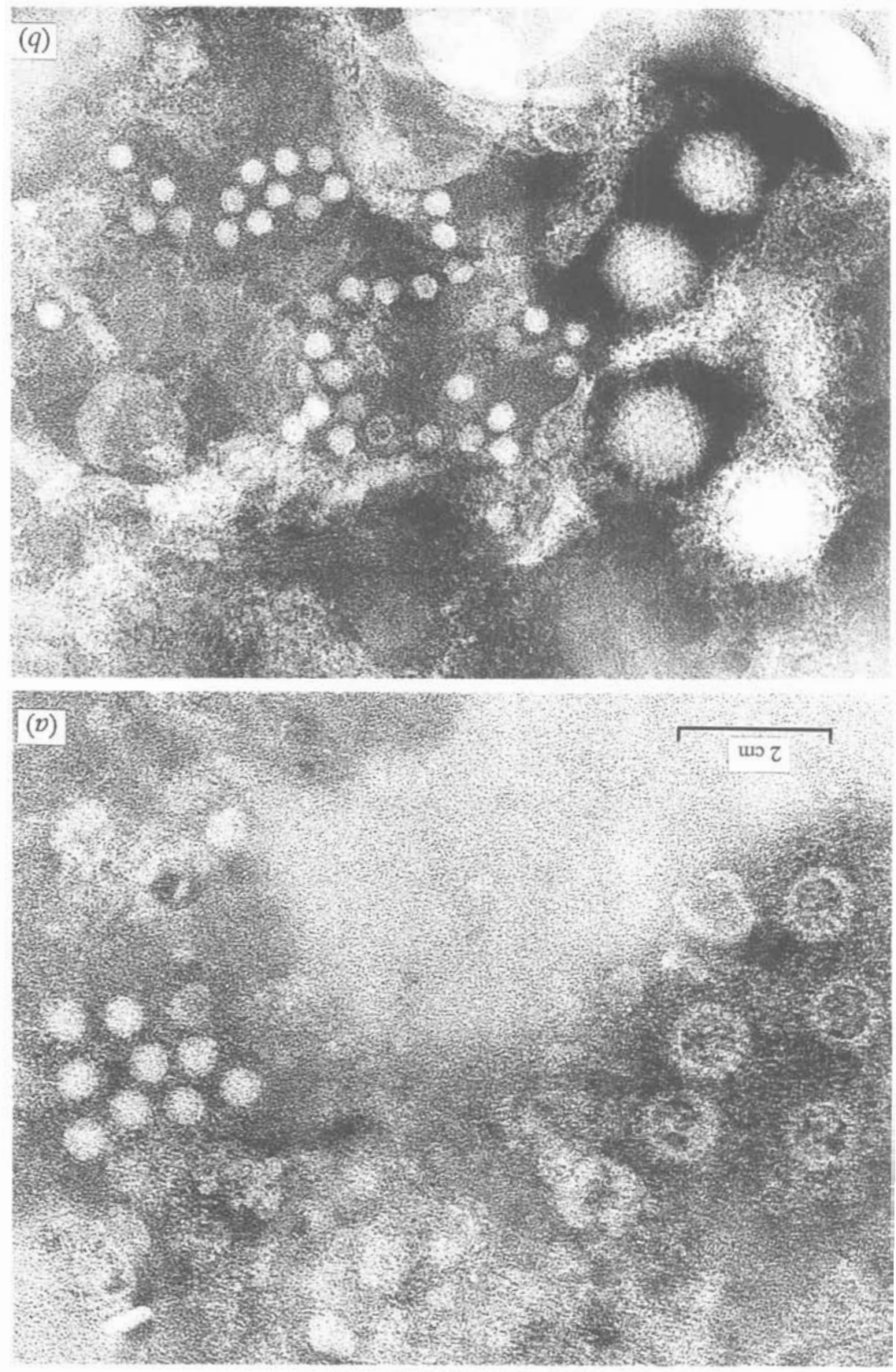

Fig. 2. Viruses detected in the stools. (a) Rotavirus and small round virus in the same stool sample. (b) Adenovirus and small round virus in the same stool sample. Bar indicates $100 \mathrm{~nm}$. 
Table 2. Detection of more than one virus type in the same stool of patients

\begin{tabular}{l}
\multicolumn{1}{c}{ Virus } \\
Rotavirus + astrovirus \\
Rotavirus + CVLP \\
Rotavirus + adenovirus \\
Rotavirus + calicivirus \\
CVLP + adenovirus \\
CVLP + SRV \\
CVLP + adenovirus + SRV \\
Adenovirus + SRV \\
Astrovirus + calicivirus \\
$\quad$ Total
\end{tabular}

Diarrhoeal
patients
2
1
1
1
0
0
1
1
1
8

\section{Control patients}

0

0

0

0

1

3

0

1

0

5
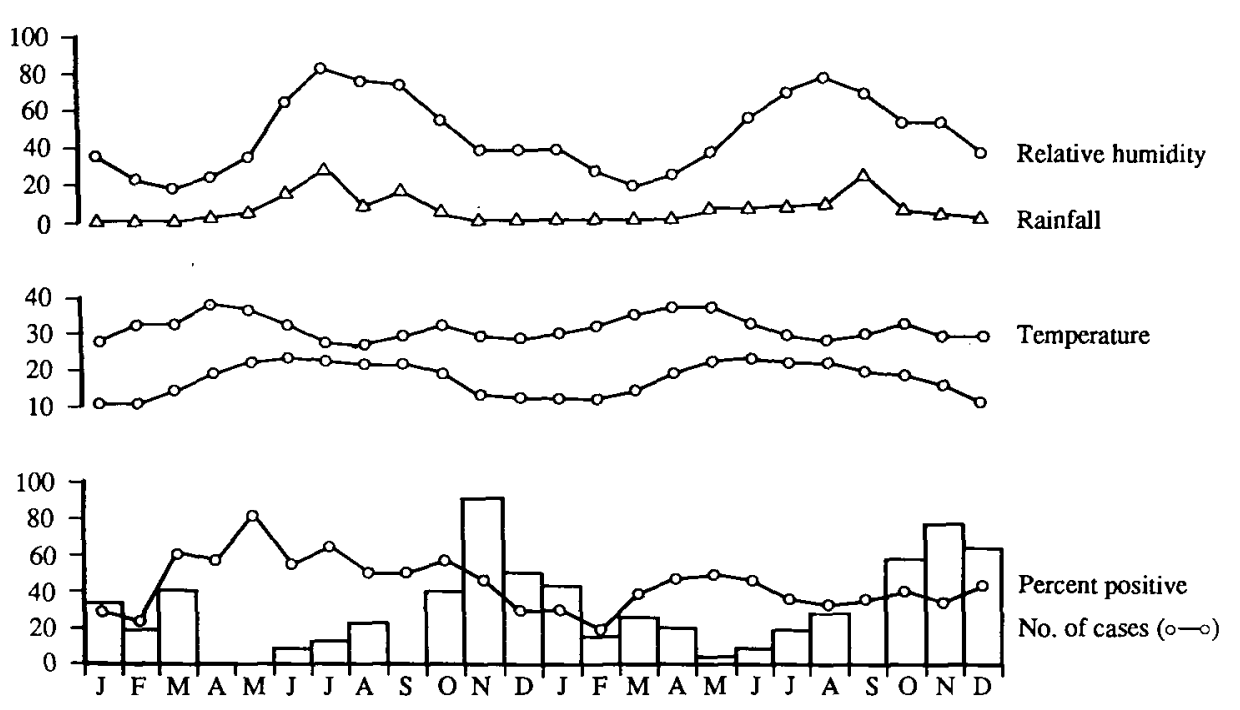

Fig. 3. Monthly incidence of rotavirus diarrhoea related to climatological factors.

Table 3. Rotavirus in diarrhoeal patients

\begin{tabular}{|c|c|c|c|}
\hline $\begin{array}{l}\text { Specimens } \\
\text { collected } \\
\text { (in weeks) } \\
\text { after onset }\end{array}$ & $\begin{array}{c}\text { Number of } \\
\text { patients }\end{array}$ & $\begin{array}{l}\text { Rotavirus } \\
\text { postive }\end{array}$ & Percentages \\
\hline 1 & 161 & 46 & 75.4 \\
\hline 2 & 34 & 12 & $19 \cdot 7$ \\
\hline 3 & 8 & 2 & $3 \cdot 3$ \\
\hline$>3$ & 10 & 1 & $1 \cdot 6$ \\
\hline
\end{tabular}

seasonal distribution was $10 \cdot 1 \%$ in summer (February to May), $9 \cdot 2 \%$ during the monsoon (June to September) and $8.5 \%$ in the winter months (October to January). In the control group, the prevalence of CVLP was $35.6 \%$ in summer compared with 13.2 and $15.5 \%$ in the monsoon and winter respectively.

The prevalence of CVLP and rotavirus was compared by age groups over and under 2 years among diarrhoeal and control cases (Table 5). In diarrhoeal cases the incidence of CVLP $(8.4 \%)$ was significantly less $(P<0.001)$ than that of rotavirus 
Table 4. Clinical features in diarrhoeal children

\begin{tabular}{|c|c|c|c|c|c|}
\hline \multirow[b]{2}{*}{ Symptoms } & \multirow[b]{2}{*}{$\begin{array}{l}\text { No. of } \\
\text { children }\end{array}$} & \multicolumn{2}{|c|}{ Rotavirus detected } & \multicolumn{2}{|c|}{ Rotavirus not detected } \\
\hline & & $\begin{array}{l}\text { No. of } \\
\text { children }\end{array}$ & $\begin{array}{l}\text { Duration of } \\
\text { symptoms } \\
\text { (in days) }\end{array}$ & $\begin{array}{l}\text { No. of } \\
\text { children }\end{array}$ & $\begin{array}{l}\text { Duration of } \\
\text { symptoms } \\
\text { (in days) }\end{array}$ \\
\hline Diarrhoea & $\begin{array}{c}213 \\
(100)^{*}\end{array}$ & $\begin{array}{c}61 \\
(100)\end{array}$ & $7 \cdot 4$ & $\begin{array}{l}152 \\
(100)\end{array}$ & 10.9 \\
\hline Fever & $\begin{array}{c}159 \\
(74 \cdot 7)\end{array}$ & $\begin{array}{c}48 \\
(78 \cdot 7)\end{array}$ & $4 \cdot 0$ & $\begin{array}{c}111 \\
(73 \cdot 0)\end{array}$ & $6 \cdot 9$ \\
\hline Vomiting & $\begin{array}{c}150 \\
(70 \cdot 4)\end{array}$ & $\begin{array}{c}44 \\
(72 \cdot 1)\end{array}$ & $3 \cdot 6$ & $\begin{array}{c}106 \\
(69 \cdot 7)\end{array}$ & $4 \cdot 2$ \\
\hline Cough & $\begin{array}{c}71 \\
(33 \cdot 3)\end{array}$ & $\begin{array}{c}13 \\
(21 \cdot 3)\end{array}$ & $4 \cdot 2$ & $\begin{array}{c}58 \\
(38 \cdot 2)\end{array}$ & $6 \cdot 8$ \\
\hline Dehydration & $\begin{array}{c}188 \\
(88 \cdot 3)\end{array}$ & $\begin{array}{c}54 \\
(88 \cdot 5)\end{array}$ & - & $\begin{array}{c}134 \\
(88 \cdot 2)\end{array}$ & - \\
\hline
\end{tabular}

* Figures in parentheses indicate percentage.

Table 5. Prevalence of CVLP and rotavirus in age groups over and under 2 years

\begin{tabular}{|c|c|c|c|c|c|c|}
\hline \multirow[b]{2}{*}{$\begin{array}{l}\text { Age } \\
\text { group }\end{array}$} & \multicolumn{3}{|c|}{ Diarrhoeal patients } & \multicolumn{3}{|c|}{ Control patients } \\
\hline & $\begin{array}{l}\text { Sample } \\
\text { size }\end{array}$ & CVLP & $\begin{array}{l}\text { Rota- } \\
\text { virus }\end{array}$ & $\begin{array}{c}\text { Sample } \\
\text { size }\end{array}$ & CVLP & $\begin{array}{l}\text { Rota- } \\
\text { virus }\end{array}$ \\
\hline $\begin{array}{l}<2 \\
\text { years }\end{array}$ & 186 & $\begin{array}{l}13 \\
(7 \cdot 0)^{*}\end{array}$ & $\begin{array}{c}50 \\
(26.9)\end{array}$ & 145 & $\begin{array}{c}41 \\
(28.3)\end{array}$ & $\begin{array}{c}3 \\
(2 \cdot 1)\end{array}$ \\
\hline $\begin{array}{l}>2 \\
\text { years }\end{array}$ & 27 & $\begin{array}{c}5 \\
(18.5)\end{array}$ & $\begin{array}{c}2 \\
(7 \cdot 4)\end{array}$ & 68 & $\begin{array}{c}8 \\
(11 \cdot 8)\end{array}$ & 0 \\
\hline Total & 213 & $\begin{array}{c}18 \\
(8 \cdot 4)\end{array}$ & $\begin{array}{c}52 \\
(24 \cdot 4)\end{array}$ & 213 & $\begin{array}{c}49 \\
(23 \cdot 0)\end{array}$ & $\begin{array}{c}3 \\
(1 \cdot 4)\end{array}$ \\
\hline
\end{tabular}

* Figures in parentheses indicate percentage.

$(24.4 \%)$. In contrast, the prevalence of CVLP (23.0\%) in the control group was significantly more $(P<0.001)$ than that of rotavirus $(1.4 \%)$. CVLP were found in $7.0 \%$ of diarrhoeal cases under 2 years of age as opposed to $26.9 \%$ with rotavirus; whereas in patients over 2 years the prevalence of CVLP was more $(\mathbf{1 8 . 5} \%)$ than that of rotavirus $(7 \cdot 4 \%)$. CVLP was found in association with other viruses in 2 out of 8 diarrhoeal cases and in 4 out of 5 controls (Table 2).

In addition to the detection of rotavirus and CVLP in the stools of diarrhoeal and control patients, adenovirus, astrovirus, calicivirus and SRV were visualized either alone or in association with each other (Figs. 1 and 2).

\section{DISCUSSION}

In the present study we have demonstrated the presence of six morphologically distinct viruses in the stools of children with clinical symptoms of gastroenteritis. These were rotavirus, CVLP, adenovirus, astrovirus, calicivirus and SRV. Several isometric and tailed bacteriophages were also detected in the stool samples. The earlier electron microscopic studies reported from South India had shown only rotaviruses, CVLP and adenovirus in the stool (Holmes et al. 1974; Mathan et al. 
1975). Recently, Panikar, Mathew \& Mathan (1982) showed the presence of astrovirus, calicivirus and SRV in diarrhoeal stools of South Indian children. In the present study these viruses were also detected in the stools of Pune children with or without the clinical symptoms of diarrhoea.

Rotavirus was detected in $28.6 \%$ of diarrhoeal patients and in only $1.4 \%$ of the control patients $(P<0.001)$. Rotavirus constituted $63.9 \%$ of all the viruses detected in the diarrhoeal cases, suggesting that they are aetiologically associated with diarrhoea in Pune children. The overall prevalence of rotavirus recorded in our study agrees with other studies reported from South India (Maiya et al. 1977; Panikar, Mathew \& Mathan, 1982). Rotavirus was detected in the stools of diarrhoeal patients almost throughout the year, although a marked seasonal prevalence was noted with a larger number of cases occurring in the cooler months of November and December.

The age distribution of rotaviral diarrhoea observed in this study suggests that infants from birth to 12 months are highly susceptible to infection. Incidentally, the proportion of children with gastroenteritis investigated in this age group was also higher ( 158 children, i.e. $74 \cdot 1 \%$ ). Rotavirus was not detected in the stools of children aged between 5 and 12 years, possibly due to the acquisition of immunity by this age.

There was not much difference in the percentages of children showing signs and symptoms of dirrhoea, fever, vomiting etc. in rotavirus-positive and negative groups. Comparison of the mean duration of the clinical features in general showed a shorter duration in rotaviral cases as compared to those with non-rotaviral diarrhoea. However, a distinct clinical profile was not discernible in the cases suffering from rotaviral gatroenteritis.

CVLP were detected more frequently in the stools of controls rather than in diarrhoeal cases $(P<0 \cdot 001)$. This conforms with the observations made earlier by Schnagl et al. (1978) among Australian aboriginals, and by Sitbon (1985) in Gabon, Africa. The other interesting feature was the higher prevalence of CVLP in summer months among Indian children rather than during the monsoon (Sitbon, 1985) and winter. A comparison of the data on the prevalence of CVLP and rotavirus in children below and over 2 years of age indicated an age-dependent relation between these two viruses in diarrhoeal patients. While the prevalence of CVLP in diarrhoeal patients increased with age, the prevalence of rotavirus declined. An inverse relationship was observed between CVLP and rotavirus flora in the gastrointestinal tract of children below 12 months of age (Fig. 4). However, further investigations are required to discover whether there is a correlation between rotavirus and CVLP.

Adenovirus alone was seen in an equal number of cases with diarrhoea and controls. It was also found associated with rotavirus, CVLP and SRV. The extent of its true involvement in the aetiology of gastroenteritis is not clear.

The astrovirus and calicivirus detected in this study were characterized on the basis of the morphological features described earlier (Madeley \& Cosgrove, 1975, 1976). While astrovirus was seen in the stools of 4 children with diarrhoea, calicivirus was seen in only 2 diarrhoeal cases. In 4 of these 6 cases rotavirus was also detected in the same stool sample. None of the control group demonstrated astro- and caliciviruses. 


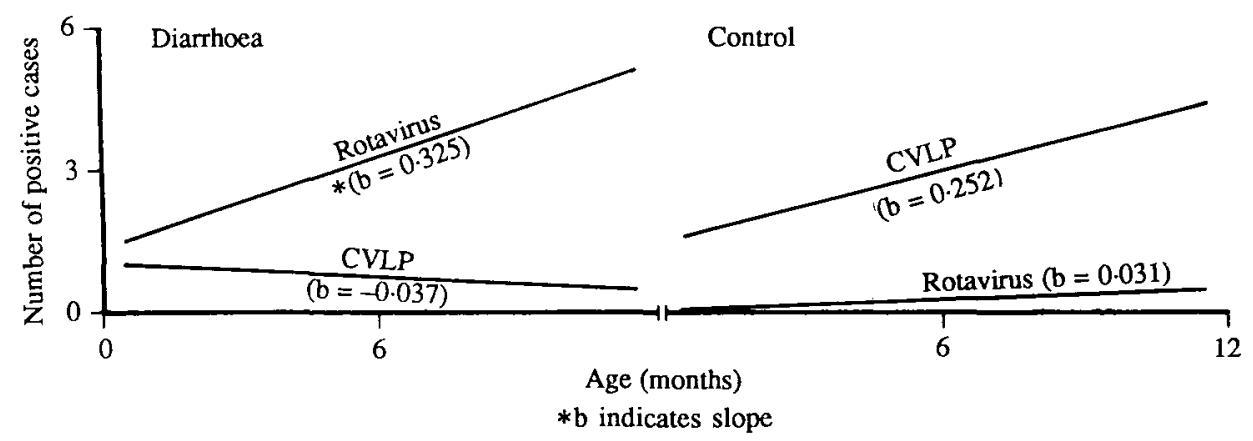

Fig. 4. Relationship of CVLP and rotavirus in diarrhoeal and non-diarrhoeal children.

In addition to astrovirus and calicivirus, small round virus-like particles were recorded in the stools of 11 children. Of these, 5 cases were associated with diarrhoea and 6 were from the control group. The identity of SRV detected in the present study needs further virological and serological investigations specially to detect Norwalk-like agents.

The authors thank Professor M. A. Phadke and Dr S. K. Raut, Sassoon General Hospitals, Pune for co-operating in this study. We also thank Mr Y. V. Ghag for photographic assistance and Mrs N. K. Athalye and Dr R. P. Deolankar for statistical assistance.

\section{REFERENCES}

Beards, G. M., Campbell, A. D., Cottrell, N. R., Peiris, J. S. M., Rees, N., Sanders, R. C., Shirley, J.A., Wood, H. C. \& FlewetT, T. H. (1984). Enzyme linked immunosorbent assays based on polyclonal and monoclonal antibodies for rotavirus detection Journal of Clinical Microbiology 19, 248-256.

Holmes, I. H., Mathan, M., Albert, M. J., Swaminathan, S. P., Maiya, P. P., Pereira, S. M. \& BAKER, S. J. (1974). Orbiviruses and gastroenteritis. Lancet ii, 658-659.

Madeley, C. R. \& Cosgrove, B. P. (1975). Viruses in infantile gastroenteritis. Lancet ii, 124. Madeley, C. R. \& Cosgrove, B. P. (1976). Calicivirus in man. Lancet 1, 199-200.

Madeley, C. R., Cosgrove, B. P., Bell, E. J. \& Fallon, R. J. (1977). Stool viruses in babies in Glasgow. 1. Hospital admissions with diarrhoea. Journal of Hygiene, 78, 261-273.

Maiya, P. P., Pereira, S. M., Mathan, M., Bhat, P., Albert, M. J. \& Baker, S. J. (1977). Aetiology of acute gastroenteritis in infancy and early childhood in Southern India. Archives of Diseases in Childhood 52, 482-485.

Mathan, M., Mathan, V. I., Swaminathan, S. P., Yesudoss, S. \& Baker, S. J. (1975). Pleomorphic virus-like particles in human faeces. Lancet $\mathrm{i}, 1068-1069$.

Panikar, C. K. J., Mathew, S. \& Mathan, M. (1982). Rotavirus and acute diarrhoeal disease in children in a Southern Indian coastal town. Bulletin of the World Health Organization 60 , 123-127.

Schnagl, R. D., Holmes, I. H. \& Mackay-Scollay, E. M. (1978). Coronavirus-like particles in aboriginals and non-aboriginals in Western Australia. Medical Journal of Australia i, 307-309.

Sitbon, M. (1985). Human enteric coronavirus-like particles (CVLP) with different epidemiological characteristics. Journal of Medical Virology 16, 67-76. 